MAREK KAŹMIERCZAK

Institute of European Culture Adam Mickiewicz University in Poznań

\title{
Modernity and existence from a semiotic angle. The Voyeurism of the City in Struktura kryształu (1969), a film directed by Krzysztof Zanussi
}

\begin{abstract}
Kaźmierczak Marek, Modernity and existence from a semiotic angle. The Voyeurism of the City in Struktura kryształu (1969), a film directed by Krzysztof Zanussi. "Images" vol. XXII, no. 31. Poznań 2017. Adam Mickiewicz University Press. Pp. 103-112. ISSN 1731-450X. DOI 10.14746/i.2017.31.10.

Krzysztof Zanussi's Struktura kryształu [The Structure of Crystals] is a film not only semiotically but also mythologically rich, in the context of myths as understood and proposed by Roland Barthes. The article explores the binary nature of the film's symbolic layer, built upon the two distinct life realities: the metropolitan vs the rural, the prestige of an academic career vs the simplicity of a family life that the main characters chose for themselves.
\end{abstract}

KEYwords: Struktura krysztatu [The Structure of Crystals], Krzysztof Zanussi, film semiotics, Barthesian myth, affordance, modernity, alienation, urban space

Struktura kryształu [The Structure of Crystals] (1969) is not a film that directly addresses urban or rural spaces, but it addresses space as semiotic and axiological contexts of the existential state of the individual. This state is reflected in the projected images and realities of a province, for which the city serves as a background, and at the same time, is something alien. The city is presented partly though the experiences of the lead characters, and partly from occassional peeks and glimpses of it.

The choice which Jan, one of the film's main characters, has to make is truly existential: it is a choice between that which gives life sense, and that which could no longer; a choice between nature and modernity. The other hero of the film, Marek, likewise has to come to a choice when he realizes that the world he thought was objective from his perspective was just a world seen from a single point of view: his own. Thus, he comes to understand why Jan will not return to the university for academic reasons; he understands why Jan, who almost died on a mountain trip, chose a life in the province, in a place which is four hours away from Warsaw, and why is this choice completely natural and is not an attempt to escape from the world. Jan ultimately chooses a world that is free from the modern civilization, the pace, social games and attractions, gadgets, luxury cars and splendour, which
Images vol. XXII/no. 31 Special Issue Poznań 2017 ISSN 1731-450X 
life actual value, albeit material, not spiritual. The objects, the attributes of modernity with which Marek tries to "tempt" Jan, were luxury items in communist Poland, illustrations of the material excess of the West. Jan, however, chose a world on the "outskirts" of modernity. He does not entirely abandon it as he still takes advantage of the fruits of civilization, depending on his needs. Nor is he post-modern, as he reads the classics of philosophy, remains faithful to tradition, and speaks of universal ideas and axiologies that cannot be relativised, particularly when commenting on Marek's intellectual dishonesty: "Jan: But you didn't help them at all; that's a filthy trick you played on them, wouldn't you say so?" In this dialogue Jan assumes the right to contemplate on the idea of infinity, to read literary and philosophical works, to do unimportant things (e.g. 31:25 seconds into the film), which are ordinary and repetitive but free one from masks and pretensions. This provincial, sleepy, oneiric world is starting to appeal to Marek. The lightness of being frees one from artificiality, from opportunism mistaken for scholarly passion. When he returns to Warsaw in his fashionable car, he puts on his shades as if putting on the mask which hides his deeply hidden true self. He then once again becomes the academic scholar who has been to the United States on a grant (1:13 minutes into the film), and modernity once again becomes a screen to his true desires. The gesture of putting on the dark glasses, which is vital in the final scene of the film, shows that Marek had thrown away the mask only for a moment, when he was with Jan and his wife Anna. Upon entering the tranquil world of Chekhov, Marek faced the difficult truth about himself, and discarded modernity for a moment.

With Struktura kryształu I am aware of the number and variety of analytical and critical angles of the film. Research done on the film has focused on different aspects: on its poetics[1]; on its intellectual and axiological considerations[2]; on the world presented in it[3]; on contrasting treatments of the film, whether as an autonomous product, or as a part of an artistic or social whole of the director's lifework [4]; or on the ideological tone of the period[5]. Mariola Marczak shows that Struktura krysztatu is one of the works most commonly cited by film experts in the survey conducted by "Film Quarterly" on the 1ooth anniversary of cinema[6]. This film is the "symbol" of 1969 in the book Historia kina polskiego [The History of Polish Cinema] edited by Tadeusz Lubelski and Konrad J. Zarębski[7]. In the article Sztuka wyboru [The Art of Choice] Małgorzata Hendrykowska writes that Krzysztof

[1] M. Marczak, Niepokój i tęsknota. Kino wobec wartości. O filmach Krzysztofa Zanussiego, Olsztyn 2011.

[2] M. Hendrykowska, Sztuka wyboru, <http://www. filmotekaszkolna.pl/dla-nauczycieli/materialy-filmoznawcze/sztuka-wyboru> [accessed on: 21.11.2017]; A. Luter, W poszukiwaniu sensu $\dot{z} y c i a,<$ http://www. akademiapolskiegofilmu.pl/pl/historia-polskiego-fil- mu/artykuly/w-poszukiwaniu-sensu-zycia/341> [accessed on: 21.11.2017].

[3] M. Hendrykowska, op.cit.

[4] M. Marczak, op.cit.; A. Luter, op.cit.

[5] M. Hendrykowska, op.cit.; A. Luter, op.cit.

[6] M. Marczak, op.cit., p. 113.

[7] T. Lubelski, K.J. Zarębski (eds.), Historia kina polskiego, Warszawa 2007. 
Zanussi's film has been analyzed for almost 30 years and is still open to new interpretations [8]. I daresay it is one of the few Polish films from that period that has gained in relevance. Time has made the problems and questions of the film's heroes even more keen and urgent, proving the interpretative potential of the film. This idea mirrors Theo van Leeuwen's concept of semiotic resource as proposed in his "Introducing Social Semiotics" where Struktura krysztatu is supported not only on the level of potential meaning, but also on the level of affordance[9]. "Affordance" was initially translated into Polish as "dostarczant", [10] but afordancja or "affordance" has become the accepted term.

Theo van Leeuwen defines the difference between meaning and affordance in this way: "The difference is that the term 'meaning potential' focuses on meanings that have already been introduced into society, whether explicitly recognized or not, whereas 'affordance' also brings in meanings that have not yet been recognized, that lie, as it were, latent in the object waiting to be discovered." [11] In the context of Struktura krysztatu it can be said that what we see and interpret that coincides with the images on the screen is a reading of the meaning potential already contained in the image. In contrast, that which we see in diachrony with the film image appears to be likewise recognition of meaning understood as affordance, that is, something which can be discovered and named due to the shifting intellectual and cultural contexts, as well as the varying cognitive perspective. In the latter part of the study I will concentrate on Struktura krysztatu as an individual and autonomous work, taking from it not only its meaning potential, but also its affordance, paying particular attention to the voyeurism of the city from the visual, linguistic and narrative perspective which Jan and his wife Anna are put under.

This is the hypothesis which I will try to prove: the existence of man in the second half of the 2oth century gave the urban landscape varied meanings, and at the same time, urban spaces shape cognitive and moral limits. A cultural text illustrating this hypothesis is Krzysztof Zanussi's film. Modernity in the said film is semantic affordance, something which is imposed on the lead character by his friend Marek, through visual and verbal signs (through the slides which showed skyscrapers or photos of a life of luxury) of the city which Jan got to know but rejected. The film Struktura kryształu is full of dynamic meaningful symmetries on the level of the characters (e.g. Jan and Marek), on the level of signs playing specific roles (e.g. photographs of crystals presented by the professor in his lectures for the people of the village, or the piece of crystal taken by a boy after the lecture), and on the level of semiotics (e.g. the images of mountains and skyscrapers that we see are slides and photographs although at the same time they connote images that are as far apart from each other in the worlds they

[8] M. Hendrykowska, op.cit.

[9] Th. van Leeuwen, Introducing Social Semiotics, London and New York 2005, pp. 31-32.
[10] T. Dant, Kultura matetialna w rzeczywistości społecznej, trans. J. Barański, Kraków 2012.

[11] Th. van Leeuwen, op.cit., p. 5. 
represent and carry completely different existential experiences (29:24 and 41:33 into the film)).

The semiotics of the town shown in Struktura kryształu introduces three frames of reception: (1) as a narrative told by Marek; (2) through photographs of the city and the lifestyle associated with it; (3) as direct experience. What unites these is the association of the city with modernity and with the feeling of alienation, anonymity, and rootlessness. The people who appear in the world of Jan and his wife have names; the people presented by Marek are carriers of media, anonymous elements of modernity, urban balusters.

In introducing the Manichean division of the body and soul one can claim that the city in Struktura kryształu is a body which subjugates the soul, the man. If we agree with that interpretation, then we also accept the hypothesis that the city in the film is treated as a fully mature work of modernity, one which does not give any doubt as to its influence on human existence (after all, in the cognitive context, many offer their "Harvards", scholarships, cinemas; meanwhile, life in the ethical context forces people to play games in which the end justifies the means, and morals corrode at the speed of a VW Beetle).

The city in Struktura kryształu appears through something, through the slides or someone's stories, which is why it seems to be an important context for existential queries and dilemmas that the lead characters experience. At the same time, the city becomes an object observed from a distance The city becomes at once something that is observed and therefore constitutes a space of distance resulting from the tension between the individual and the collective. The reality of the province, in contrast, is intimate and filled with close-ups, and the frames are mostly shot from a single angle. Irvin Yalom, an American psychotherapist and author of the concept of existential psychotherapy, writes that a man is burdened with four basic existential concerns. [12] If so, then one must assert that the modern city intensifies and embodies them. The first, modernity, is not so much erotic as thanatic, which is why the space which is filled with geometric forms that organize emptiness that turns out to be a semiotic repetition of death in the language of architecture. Freedom as another existential concern follows man in the pursuit of his place in the world, which is why Marek surrounds himself with luxury and his career is symbolized vertically by the skyscrapers which were unknown in the communist period. Marek criticizes the world of the village, the world of Jan, for lacking structure and predictability. The modernity which is represented by Marek expresses fear of isolation, the third existential concern. Marek desires contact, protection, belonging to a community where each one has a name and a story. On his visit to Jan, he takes off his mask and reveals his need to belong and his overwhelming fear of isolation. The skyscrapers are "artificial crystals" of modernity in which their "structure" is insula-

[12] I.D. Yalom, Psychoterapia egzystencjalna, trans.

A. Tanalska-Dulęba, Warszawa 2008, pp. 16-17. 
tion (il. 1). The fourth existential concern is the lack of sense. Marek, surrounded by things, intoxicated by his career, convinced of his own perfection, does not find the sense in life which Jan has, and which is the basis for his choice of a world wherein existence takes precedence over matter. Modernity on the level of content and form does not bring Marek consolation. Irvin Yalom is right in saying that people are more miserable than they think.[13] The city becomes a form which determines existence, but does not give them comfort. What it does is force them to a life which is inconstant, uncertain, and unstable, where things become a prosthetic for the closeness of another human being.

Let us look at the slides of the skyscrapers - vertical spaces, geometrical, organized, almost fractal with its numerous repetitions of basic geometric figures in different sizes the windows and the whole building. And not a single human being. Modernity in Vattimo's understanding is characterized by "dialectic

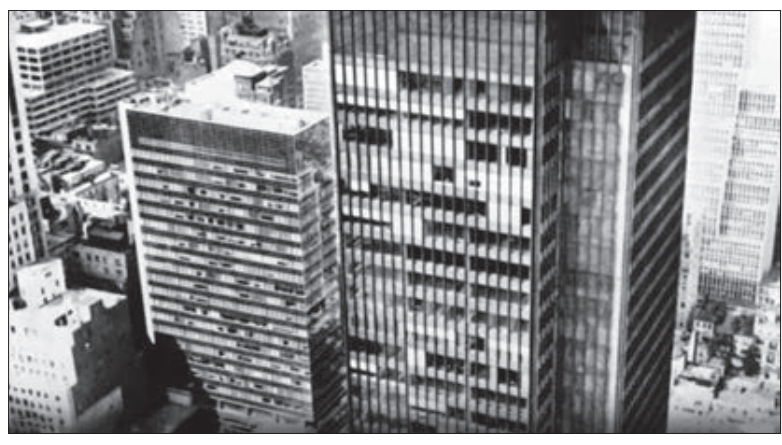
Überwindung - the bearing, crossing, and rejecting of used and obsolete definitions of reality in the name of creating new, more ideal, more relevant and adequate ones." [14] Marek travels from such a "new, relevant, and more ideal" world as compared to the world of Jan, where he learns how to create articficial crystals and becomes a professor. This world Il. 1. Frame from Struktura krysztatu presenting images of American skyscrapers, seen by the lead characters through slides is existential scaffolding. Marek shows Jan an advertisment for Ford Torino GT 8 and says: "Can you see this?" as if he wanted to actually say, "you see, this is the real world", and by doing so, also expresses a total afirmation of this world (17:7 into the film, il. 2). Cognitive prosthetics (in Paris he saw "Three Sisters" with Marina Vlady, and Małgorzata Hendrykowska says: "The Chekhov are not antiquated, but 'seen' in Paris" [15]). The axiological content justifies the precedence of its own perspectives inherently contained in the relationships of people in the city.

Jan: But you didn't help them at all. That's a filthy trick you played on them, wouldn't you say so?

Marek: Yes.

Jan: Just like that?

Marek: Yes.

Jan: So, you're a cynic?

Marek: No, a realist. I took a chance and I won. It's war out there. You don't shoot, you get shot.

Marek, being the "soul of the city" and coming from it, represents modernity which Vattimo calls "progressive enlightenment" [16] which

[13] Ibidem, p. 20.

[14] A. Zawadzki, Koniec nowoczesności: nihilizm, hermeneutyka, sztuka, in: G. Vattimo, Koniec nowoczesności, trans. M. Surma-Gawłowska, Kraków 2006, p. VIII.
[15] M. Hendrykowska, op.cit.

[16] G. Vattimo, op.cit., p. 2. 


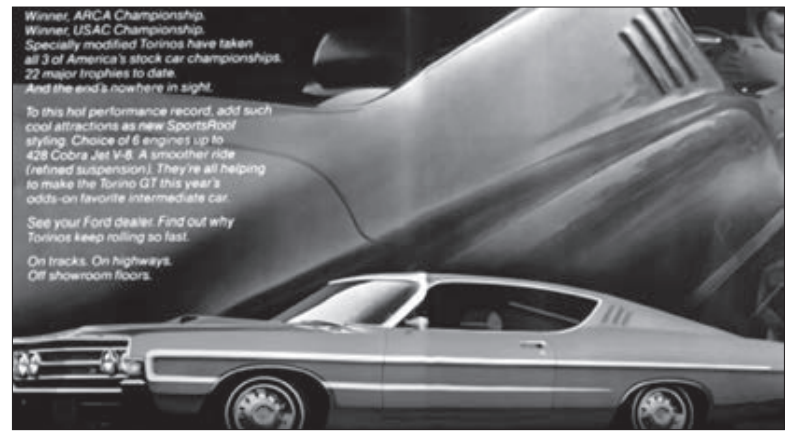

Il. 2. Frame from Struktura kryształu presenting a Ford with which Marek is enamoured, seeing in the car the embodiment of all the desires of the modern man is characterized by the appropriation and usurpation of fundamental values.

Marek wants to have Jan, and Jan's wife, for himself and lead them to modernity, tempting them with its pleasures by using religious metaphors. This is no accident, as Jan and Marek mirror to some degree the scene of the temptation of Christ:

Again, the devil took him to a very high mountain and showed him all the kingdoms of the world and their splendor. "All this I will give you," he said, "if you will bow down and worship me." Jesus said to him, "Away from me, Satan! For it is written: 'Worship the Lord your God, and serve him only." Then the devil left him, and angels came and attended him. (Mt 4,1-11)

Marek shows Jan slides of American life and images from glossy magazines and offers him "all the kingdoms of the world and their splendor". However, there is a price: life in this world requires giving up one's right to personal freedom as one needs to conform to the mechanisms set in place by the powers-that-be, in which the foundation of existence is one's downfall. The high-rise buildings in the slides are the "very high mountains" from which one can fall easily, particularly when one gives up the right to one's own existence.

Jan and Anna do not want to move to the city, nor do they want to take advantage of the conveniences the city has to offer. They find the perspective presented by Marek somewhat enchanting; after all, the city is movement, it is a constant state of change in various forms, not only in buildings and things like luxury cars, but also in the variety of symbols of life, habits, traditions. Anna gladly takes lessons in popular dances of the West from Marek: the West means the modern, and by extension, the city. Jan does not reject Marek's proposition outright, there is an inner conflict; the desire for life in "all the kingdoms of the world" is great, and at the very least, he wants to offer his wife a different life. Jan knew that he had somewhere to go, that the Professor and a potential career are waiting for him. Returning to Warsaw in this case is a great temptation for Jan. The final scene of the film is quite telling: we see Jan looking back at Marek as the embodiment of everything offered by the city. Marek is the figurative apple, an object of desire and temptation slowly disappearing from our sight or slipping from our hands, daring us to make one final lunge for it. Jan and Anna, however, no longer belong to that world: Anna criticizes a love scene in a film and mistakes Olbrychski with Łomnicki (50:36 of the film). Still, the city in the eyes of the lead characters partly reflects their demeanor and their choices: Anna wants to buy a hat, Jan says it's a good idea but she wouldn't be able to wear the hat to work. The first scene of the city Jan and Anna arrive at is in complete contrast with the scenes from the slides seen previously. Puława is a city in construction and is in 
such a state that modernity has not yet settled but is starting to show some signs of modern features: electrical installations, technological constructions, shop windows, commercial billboards, libertine lifestyle depicted by film stars in film posters. Jan and Anna no longer belong to the city, they have been uprooted from this environment and speak of it in the style of Polska Kronika Filmowa (a Polish newsreel). Anna, for instance, points to a factory in Puława and describes it as if reading from an encyclopedia entry: "One of the largest in Europe. Provides half of the national production. Highly automatized." Or, they contest the superficial objectivity of the city courts that cognitively or morally limit man. The modern man is efficient and enters into a relationship only when there is profit for him to do so. The scene in the village inn (Illustration 3 ) is relevant to this: we see closeups of the so-called simple folk with whom Jan and Marek are drinking.

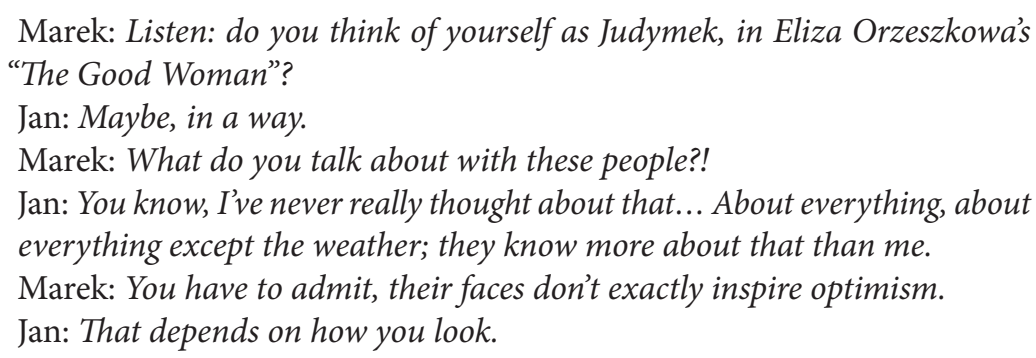

Talking for the sake of talking seems impractical and unnecessary to Marek. Modernity as progressive enlightenment seems in this context a distortion of human relationships. The modern man situates himself in this context as someone better than others, and in isolating himself from others he paradoxically conceals the fact that he himself is afraid of isolation. Diminishing the worth of others gives Marek the impression that he controls the world in which he exists.

Referring to the philosophical tradition, one can say that Jan looks at reality from an

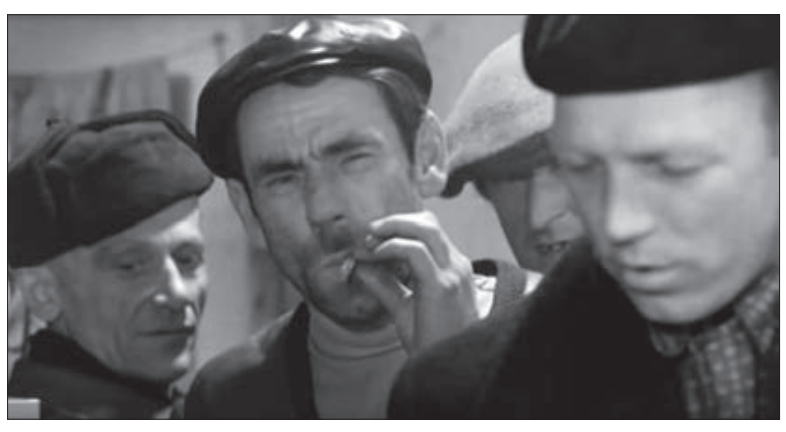
angle. In rejecting the reality of the city, he achieves his own Copernican revolution as when he says, "It depends on how you look." Thus, Marek is right when he sees a a big bright modern world; but in a sense, everyone at some level is right. Semantic affordance allows me to asIl. 3. Scene from the film Struktura krysztalu showing the "simple" folk whom Marek despises sume that the reality seen in Struktura kryształu is always fragmented, and not because of the demands of the poetics of the film, but because there is no cognitive perspective which is holistic. This is probably why we see Puława as a city in construction, as if Jan and Anna wanted to show Marek that this is their world, and not other, and at the same time, this is not their whole world. Marek the scholar, steeped in a positivist, almost scientific, perspective, falls for the illusion that what one knows of the world is the same as what the world is. This is why 
borders have become blurred - between science and existence, between the subjective and objective, between a fragment and the whole of experience. For Marek the slides of American cities are not mere stories of the world, but are the world. However, for Jan the city is that which has been rejected, alien, unwanted, exterior, a source of an alternative perspective, a point of view which is consciously dismissed. The city in Struktura kryształu "acts" through its absence, as seen in the telephone conversation between Marek and the Professor. This semiotically relevant absence emphasizes the superficiality and alienation of the city in a life so intimate as that of Jan and Anna.

Marek takes a covert look at their happiness, at their world completely separate from his own. The voyeurism of a city, just like the voyeurism of intimacy, which has a Kantian cognitive perspective, shows merely the phenomenon of reality from which we build an image of the world. The camera of Zanussi in Struktura kryształu is a metaphorical "Kantian camera", where the shifting perspective of observation focuses our gaze on the object, on the one watching, and although we do not necessarily participate in the watching, we know that we want to see more. Marek spies on Jan and Anna and learns the truth as unconcealedness (from the Greek aletheia), understanding that coming in from the outside one can always only know a fragment, a part of another's existence. Maybe this is why Marek at a certain point in the film wanted to claim Jan and Anna and force on them his perspective, to build in their lives a modern city, where human existence would be reduced to a set of instructions which have to be followed conscientiously. Marek probably wanted to objectify their world and in so doing, take away its value and impose on them his own subjectivity as the norm. This may be the most common form of human objectivity imposed subjectivity. And this may be the consequence of tempting with modernity in which objectivity is narcissistically inclined. What are glass houses for, but to duplicate our reflections; what is temptation for, but for the tempted to mirror the tempter.

The city plays an important role in the film of Zanussi. It is a city which has just been built, but it is also a city in which shoelaces and whips are sold in markets, with vendors shouting out catchy rhymes or truisms like "A good wife is a treasure for a man." [17] On the level of potential meanings we can see a piece of Poland in the late 1960s - a Poland which was in the process of being rebuilt, inhabited by different people representing contrasting attitudes and behavior, a Poland unready, unfinished, grey; modern to the limits of the social and economic possibilities at the time; a poor Poland, which has heard of colored TVs, but which could not save enough money from scholarship funds to be able to buy a second-hand VW Beetle.

[17] M. Marczak, op.cit., p. 103. 
Modernity and existence are mutually conditioned in Struktura kryształu. The fates of Jan, Anna and Marek bring to mind various figures of civilization which have a lot to offer in the subjective sphere, at the cost of the objective sphere. Struktura kryształu is a film not only semiotically but also mythologically rich in the context of myths as understood and proposed by Roland Barthes. There is an evident set of images that reflect the dynamic symmetry represented by Jan and Marek: age and youth, the village and the city, the horse and the car, natural crystals and synthetic crystals, woman and man, horizontal order and vertical order, sound and word, wisdom and science, the peasant and the professor, among many others. In a simplified paraphrase of Barthes, we can say that the universality of the film comes from its mythological potential. Marek and Jan are to each other the signifie and signifiant. From their interactions we can retrieve certain signs, e.g. the life choices one makes, of which much has been written which again becomes a signifiant sign referring to a completely different order of existential discourse. Following this train of thought, one can ask, who is Anna in her relations with Jan and Marek? As Mariola Marczak asks, is she the treasure which Jan has and Marek does not? Or maybe she is an ideal figure of asymmetry, as one equals one and two cannot equal one. Anna = Jan. Anna is different from Marek. Anna is the embodiment of the myth which grew out the dynamics of two signs and that which they connote, that is, fulfillment and unfulfillment, Jan and Marek, intimacy and the city. Figuratively speaking one can say that the city is not an erotic space in the Platonic sense. Anna and Jan form a whole, whereas Marek is incomplete, broken, halved. He lacks possibilities only in finding the right person. Maybe this is why Jan chose inner emigration, making intimacy the azimuth of the sense of life, but in this way he achieved full humanity. Marek could not achieve this because, just as a figure of the city his character, despite many assets, provokes distrust.

Using the film Struktura kryształu I have tried to show that the existence of man in the second half of the 2oth century gave urban space varied meanings, and at the same time the city forms the cognitive and moral limits. This is why the limits of our city are the borders of our language, and the limits of our language are the limits of our modern existence. The city uproots and its divides and breaks will lead merely to the mechanical and automatic symmetry of buildings, streets, cars; it is a city from which we try to escape. This city does not fill the void, the overwhelming void of the sense of life. 
Hendrykowska M., Sztuka wyboru, <http://www.filmotekaszkolna.pl/dla-nauczycieli/materialy-filmoznawcze/sztuka-wyboru> [accessed on: 21.11.2017]

Leeuwen Th. van, Introducing Social Semiotics, London and New York 2005

Lubelski T., Zarębski K.J. (eds.), Historia kina polskiego, Warszawa 2007

Luter A., W poszukiwaniu sensu życia, <http://www.akademiapolskiegofilmu.pl/ $\mathrm{pl} /$ historia-polskiego-filmu/artykuly/w-poszukiwaniu-sensu-zycia/341> [accessed on: 21.11.2017]

Marczak M., Niepokój i tęsknota. Kino wobec wartości. O filmach Krzysztofa Zanussiego, Olsztyn 2011

Vattimo G., Koniec nowoczesności, trans. M. Surma-Gawłowska, Kraków 2006

Yalom I.D., Psychoterapia egzystencjalna, trans. A. Tanalska-Dulęba, Warszawa 2008

Zawadzki A., Koniec nowoczesności: nihilizm, hermeneutyka, sztuka, in: G. Vattimo, Koniec nowoczesności, tłum. M. Surma-Gawłowska, Kraków 2006 